\title{
Usaha Peningkatan Daya Dukung Tanah Lempung Menggunakan Layer Krikil, Anyaman Bambu dan Kombinasi Kolom-Layer Pasir
}

\author{
Dian Eksana Wibowo ${ }^{a^{*}}$, Hermawan Wahyu Rahmadianto ${ }^{a}$, Endaryanta ${ }^{a}$ \\ ${ }^{\text {a } J u r u s a n ~ P e n d i d i k a n ~ T e k n i k ~ S i p i l ~ d a n ~ P e r e n c a n a a n, ~ F a k u l t a s ~ T e k n i k, ~ U n i v e r s i t a s ~ N e g e r i ~ Y o g y a k a r t a, ~ Y o g y a k a r t a, ~ I n d o n e s i a, ~} 55128$
}

\begin{abstract}
Keywords:

clay soil

bamboo

Gravel

Soil bearing capacity

Sand

Clay soil is soil that has a low value of pressure strength and bearing capacity. The purpose of this study is using a layer of gravel, woven bamboo, and a combination of column-layer sand as an alternative to improve the carrying capacity of clay soil, then the results from the tests are compared with each other. The method in this study is experimental. The samples of soil were taken from Kalangan, Kasihan, Bantul, D.I. Yogyakarta. The foundation soil model using steel tub size 100x100x40 cm, with soil volume 100x100x30 cm. Soil loading uses steel plates that are loaded with hydraulic jacks, equipped with a proving ring as a load reader. The column-layer combination consists of 3 sand layers, $1 \mathrm{~cm}$ thick horizontal position and $5 \mathrm{~cm}$ spacing between layers. The sand column is $1 \mathrm{~cm}$ in diameter with a hole depth of $20 \mathrm{~cm}$. The gravel layer pattern consists of 3 layers of gravel with a layer thickness of $2 \mathrm{~cm}$, the distance between the layers is $5 \mathrm{~cm}$. Woven bamboo pattern: 1 layer with a length of $20 \times 20 \mathrm{~cm}$. Placement of woven bamboo at a depth of $2 \mathrm{~cm}$ from the ground. The results of the research are; (1) The Soil is a high plasticity (CH) inorganic clay based on the USCS system, including the medium to poor clay soil group (A-7-6 (40)) based on the AASHTO system. (2) The Strengthening of gravel layer increases the ultimate bearing capacity by 2.5 times or $159.02 \%$, while bamboo matting provides an increase in bearing capacity by 2.7 times or $170.49 \%$, and the combination of column-layer sand by 2.2 times. or 127, 87\%. (3) The reinforcement of bamboo mats provides the highest increase in bearing capacity in clay soil between the gravel layer and the combined reinforcement of the sand column and the sand layer. This shows that the use of woven bamboo is more effective as a material for strengthening clay.
\end{abstract}

Kata kunci:

Tanah lempung

Daya dukung tanah

kerikil

bambu

pasir

\section{ABSTRAK}

Tanah lempung adalah tanah yang mempunyai nilai kekuatan tekanan serta nilai daya dukung rendah. Tujuan penelitian ini adalah penggunaan layer kerikil, anyaman bambu, dan kombinasi kolom-layer pasir sebagai alternatif perbaikan peningkatan daya dukung tanah lempung, kemudian hasil dari pengujian dibandingkan satu sama lain. Metode yang digunakan adalah experimen. Sampel tanah diambil dari Kalangan, Kasihan, Bantul, D.I. Yogyakarta. Pemodelan tanah pondasi menggunakan bak baja ukuran $100 \times 100 \times 40 \mathrm{~cm}$, volume tanah $100 \times 100 \times 30 \mathrm{~cm}$. Pembebanan tanah menggunakan pelat baja yang dibebani dengan dongkrak hidrolik, dilengkapi proving ring sebagai pembaca beban. Kombinasi kolom-layer pasir terdiri dari 3 lapis pasir, posisi horizontal tebal $1 \mathrm{~cm}$ dan jarak antar lapisan $5 \mathrm{~cm}$. Kolom pasir diamter $1 \mathrm{~cm}$ dengan kedalaman lubang $20 \mathrm{~cm}$. Pola layer kerikil terdiri 3 lapis kerikil dengan ketebalan lapisan $2 \mathrm{~cm}$, jarak antar lapisan $5 \mathrm{~cm}$. Pola anyaman bambu: 1 lapis dengan panjang-lebar anyaman 20x20 cm. Penempatan anyaman bambu pada kedalaman $2 \mathrm{~cm}$ dari permukaan tanah. Hasil penelitian yaitu ; (1) Tanah merupakan tanah lempung anorganik plastisitas tinggi $(\mathrm{CH})$ berdasarkan sistem USCS, termasuk kelompok tanah berlempung kualitas sedang sampai buruk (A-7-6(40)) berdasarkan sistem AASHTO. (2) Perkuatan layer kerikil meningkatkan daya dukung ultimit sebesar 2,5 kali atau 159,02 \%, sedangkan anyaman bambu memberikan peningkatan daya dukung sebesar 2,7 kali atau 170,49 \%, dan kombinasi kolom-layer pasir sebesar 2,2 kali atau 127, 87\% . (3) Perkuatan anyaman bambu memberikan peningkatan daya dukung paling tinggi pada tanah lempung diantara bahan perkuatan layer kerikil dan perkuatan gabungan kolom pasir dan layer pasir. Hal ini menunjukkan bahwa penggunaan anyaman bambu lebih efektif sebagai bahan perkuatan tanah lempung.

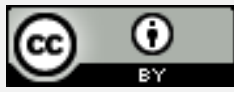

This is an open access article under the CC-BY license. 


\section{Pendahuluan}

Pembangunan infrastruktur yang berkembang pesat berdampak pada kebutuhan lahan untuk pembangunan juga semakin meningkat. Hal ini mengakibatkan pembangunan pada lokasi dengan kondisi tanah yang kurang baik seperti tanah lunak tidak dapat dihindarkan. Sebaran tanah lunak di Indonesia diperkirakan sekitar 20 juta hektar atau sekitar 10 persen dari luas total dataran Indonesia [1]. Kondisi tanah lunak dalam konstruksi seringkali menjadi permasalahan, dikarenakan tanah lunak mempunyai karakteristik daya dukung dan kuat geser yang rendah serta kompresibilitas yang tinggi. Hal tersebut dapat mengakibatkan kerusakan pada bangunan hingga mengancam keselamatan pengguna bangunan.

Kasus kerusakan bangunan akibat dasar pondasi yang berupa tanah lunak terjadi di Dusun Kalangan, Desa Bangunjiwo, Kecamatan Kasihan, Kabupaten Bantul, Provinsi Daerah Istimewa Yogyakarta. Beberapa rumah penduduk mengalami kerusakan seperti lantai dan dinding yang retak, hingga pergeseran pondasi bangunan.

Berangkat dari permasalahan tersebut, maka tanah lunak perlu diatasi yaitu dengan melakukan perbaikan tanah. Salah satu teknik perbaikan yang umum adalah perbaikan secara fisik, yaitu dengan penggunaan material geosintetik (geotekstil dan geogrid) [2]. Namun, perbaikan menggunakan geosintetik tidak bisa diterapkan pada semua lokasi pembangunan, terutama pada daerah terpencil, karena memerlukan biaya yang besar.

Pemilihan bahan alternatif perbaikan tanah yang lebih ekonomis dan memiliki kualitas yang baik menjadi solusi untuk permasalahan tersebut. Perbaikan tanah menggunakan bahan pasir, kerikil, dan bambu. Campuran lempung dan pasir pantai dengan kadar 85\% dapat mengurangi nilai CBR pengembangan [3]. Perbaikan menggunakan bahan pasir dilakukan dengan metode gabungan kolom dan layer pasir.

Menurut Pemakaian pasir pada perbaikan pondasi dangkal dengan metode Prefebricated Vertical Drain (PVD) dan Prefebricated Horizontal Drain (PHD) mengalami peningkatan daya dukung pondasi sebesar 26\% [4]. Perbaikan tanah menggunakan bahan bambu dilakukan dengan metode lapis horizontal anyaman bambu. Penggunaan teknik perkuatan dengan lapis anyaman bambu pada pondasi dangkal mengalami kenaikan daya dukung sebesar 21,079\% dibandingkan tanah tanpa perkuatan [5].
Maka pada penelitian ini dilakukan pemodelan perbaikan tanah lempung lunak menggunakan metode layer kerikil, anyaman bambu, dan gabungan kolom pasir dan layer pasir dengan pemodelan skala laboratorium untuk mengetahui efektifitas bahan tersebut dalam perbaikan tanah.

Tujuan dilaksanakannya penelitian ini adalah: (a) Mengetahui jenis tanah yang diambil dari daerah penelitian berdasarkan sistem klasifikasi tanah; (b) Mengetahui pengaruh metode perkuatan tanah dengan layer kerikil, anyaman bamboo, dan gabungan kolom pasir dan layer pasir terhadap daya dukung tanah lunak; (c) Membandingkan efektifitas dari ketiga bahan perkuatan pada tanah lunak.

\section{Tinjauan Penelitian}

\subsection{Definisi Tanah}

Tanah merupakan himpunan mineral, bahan organik, dan endapan-endapan yang relatif lepas (loose), yang terletak di atas batuan dasar (bedrock) [6]. Tanah berasal dari pelapukan batuan induk baik secara fisik atau kimia. Pelapukan secara fisik sangat dipengaruhi oleh aires, angin, dan perubahan suhu dan cuaca yang mengubah ukuran batuan menjadi partikel-partikel lebih kecil. Sedangkan pelapukan secara kimia dipengaruhi oleh oksigen, karbondioksida, dan proses kimia lainnya.

Berikut jenis tanah berdasarkan ukuran partikel: (a) kerikil (gravels), yaitu partikel batuan yang berukutan $5 \mathrm{~mm}$ sampai $150 \mathrm{~mm}$; (b) pasir (sand), merupakan partikel batuan yang berukuran $0,074 \mathrm{~mm}$ sampai $5 \mathrm{~mm}$; (c) lanau (silt) merupakan partikel batuan yang berukuran 0,002 mm sampai 0,074 mm; (d) lempung (clay) adalah partikel mineral yang berukuran lebih kecil dari 0,002 $\mathrm{mm}$.

\subsection{Tanah Lempung}

Tanah lempung terdiri dari ukuran partikel mikroskopis hingga sub mikroskopis atau lebih kecil dari 0,002 mm [7]. Sifat tanah lempung bergantung pada kadar air yang terkandung didalamnya. Apabila kadar air rendah maka tanah lempung bersifat keras, apabila kadar air sedang maka tanah lempung bersifat plastis dan apabila kadar air tinggi maka tanah lempung bersifat lengket (kohesif). Selain terkait kadar air, tanah lempung juga memiliki sifat permeabilitas rendah, kompresibilitas tinggi dan proses konsolidasi yang lama. 


\subsection{Bambu}

Bambu merupakan salah satu tanaman yang dapat dimanfaatkan dalam berabagi hal, salah satunya bambu dapat dipergunakan sebagai bahan konstruksi, yaitu sebagai rangka atap, dinding, hingga pengganti tulangan. Selain karena bambu mudah diperoleh dan harganya terjangkau, bambu juga memiliki keunggulan dari segi kekuatannya dalam hal kuat tarik. Terdapat beberapa faktor yang mempengaruhi kuat tarik bambu yaitu kadar air, bagian arah melintang bambu, dan ada tidaknya buku atau nodia [8].

Jenis bambu memiliki kuat tarik dan kuat tekan yang lebih besar dari kayu [9-10]. Kuat tarik bambu lebih besar dua kali lipat dari kayu dan kuat tekan bambu lebih tinggi sekitar $10 \%$ dibandingkan kayu. Perbandingan kuat tarik baja dengan bambu yaitu bambu mempunyai kuat tarik perunit yang lebih besar sekitar 3-4 kali dibandingkan baja [10]. Bambu memiliki kelemahan pada sisi keawetannya, yaitu sangat mudah diserang jamur dan serangga. Keawetan bambu sangat dipengaruhi olehh cuaca dan lingkungan. Bambu yang melewati proses pengawetan akan lebih tahan lama dibandingkan bambu biasa [8].

\subsection{Kerikil}

Kerikil dan batu pecah termasuk dalam agregat kasar dengan ukuran butir lebih besar dari $5 \mathrm{~mm}$ sampai ukuran $150 \mathrm{~mm}$ [11]. Penggunaan bahan kerikil dalam perbaikan tanah dapat diaplikasikan dalam berbagai bentuk dan pola. Bentuk yang paling umum digunakan adalah kolom batu (stone column) dan layer atau lapisan perkuatan.

Dalam jurnal perkuatan tanah model trapesium terhadap daya dukung tanah lempung menggunakan penambahan pasir dan batu sebagai layer atau lapisan pengisi diatas tanah dasar dan geotekstil sebagai pemisah lapisan diperoleh hasil bahwa dengan penambahan pasir dan batu dapat meningkatkan daya dukung tanah, mengurangi deformasi tanah, dan mereduksi penurunan tanah lempung [12].

\subsection{Pasir}

Pasir adalah agregat yang memiliki ukuran butir antara $0,06 \mathrm{~mm}$ sampai $2 \mathrm{~mm}$ dan terdiri dari satu macam mineral, terutama mineral kuarsa. Pasir termasuk dalam material non-kohesif, yaitu material yang mempunyai sifat ikatan antar butir lepas, susuan partikel tidak padat dan kerapatan yang rendah [13]. Penggunaan pasir dalam perbaikan tanah adalah sebagai drainase, yaitu pasir berperan untuk mengalirkan air yang terperangkap dalam tanah lempung.

Penggunaan pasir dapat diaplikasikan dalam bentuk kolom (drainase vertikal), layer (drainase horizontal), dan gabungan antara bentuk kolom dan layer. Penggunaan kombinasi layer pasir dan kolom pasir vertical (CTPVH) pada beban $0,1 \mathrm{~kg} / \mathrm{cm} 2$ paling efektif dalam proses konsolidasi yaitu sebesar $94,10 \%$ dari tanah asli (TTD) dimana mempunyai nilai sebesar nilai t90 untuk CTPVH yaitu sebesar 15,21 menit [14].

Pada penelitian pengaruh perkuatan tanah lempung dengan menambahkan kolom pasir dan melakukan variasi jarak kolom, dapat menaikkan data dukung tanah lempung sebesar $10,53 \%$ dibandingkan tanah asli tanpa perkuatan [15]. Dari hasil beberapa penelitian tersebut, dapat diketahui bahwa penggunaan bahan pasir pada perbaikan tanah lempung mampu mengurangi penurunan tanah dan meningkatkan daya dukung tanah.

\subsection{Pondasi}

Pondasi adalah komponen struktur terendah dari bangunan yang meneruskan beban bangunan ke tanah atau batuan yang berada di bawahnya [6]. Pondasi terbagi menjadi dua yaitu pondasi dangkal dan pondasi dalam. Pondasi dangkal merupakan pondasi yang hanya mampu menerima beban bangunan secara langsung dan hanya mampu menerima beban yang relatif kecil, sedangkan pondasi dalam merupakan pondasi yang mampu menerima bangunan dalam skala besar. Uji model mekanisme keruntuhan pondasi dibagi menjadi tiga macam [6]:

\subsubsection{Keruntuhan Geser Umum (General Shear Failure)}

Keruntuhan ini terjadi menurut bidang runtuh yang diidentifikasikan dengan jelas. Suatu baji tanah berbentuk tepat pada dasar pondasi zona A yang menekan tanah ke bawah hingga menyebabkan aliran tanah secara plastis pada zona B. Gerakan kearah luar dikedua zona tersebut ditahan oleh tahanan tanah pasir dibagian C. Saat tahanan tanah pada pasir bagian $\mathrm{C}$ terlampaui, terjadi gerakan tanah yang mengakibatkan penggelembungan tanah di sekitar pondasi. Saat keruntuhan, terjadi gerakan massa tanah ke luar dan ke atas. 


\subsubsection{Keruntuhan Geser Lokal (Local Shear Failure)}

Tipe keruntuhan Geser Lokal hampir sama dengan keruntuhan geser umum, namun bidang runtuh yang terbentuk tidak sampai ke permukaan tanah. Jadi bidang runtuh yang kontinu tidak berkembang. Pondasi tenggelam akibat bertambahnya beban pada kedalaman yang relatif dalam, yang menyebabkan tanah yang didekatnya mampat.

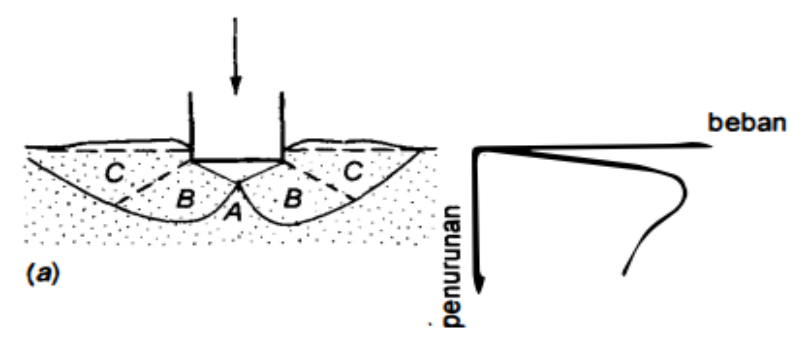

\subsubsection{Keruntuhan Penetrasi (Punching Shear Failure)}

Pada tipe ini, dapat dikatakan keruntuhan geser tanah tidak terjadi. Akibat beban pondasi hanya menembus dan menekan tanah kesamping yang menyebabkan pemampatan tanah didekat pondasi. Pemampatan tanah akibat penetrasi pondasi, berkembang hanya pada zona terbatas tepat didasar dan disekitar pondasi.

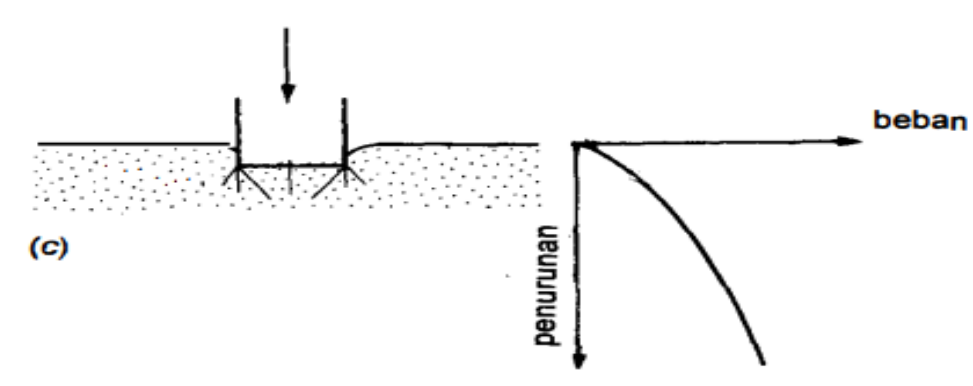

Gambar 1. Macam-macam keruntuhan pondasi (a) Keruntuhan geser umum; (b) Keruntuhan geser lokal; (c) Keruntuhan penetrasi

\subsection{Stabilitas Tanah}

Stabilitas tanah adalah suatu metode rekayasa tanah yang bertujuan untuk meningkatkan dan/atau mempertahankan sifat-sifat tertentu pada tanah, agar selalu memenuhi syarat teknis yang dibutuhkan. Stabilisasi tanah dapat dibedakan atas tiga jenis, yaitu:

\subsubsection{Stabilisasi Kimia}

Stabilitas kimia dilakukan dengan menambahkan bahan kimia tertentu pada material tanah, sehingga terjadi reaksi kimia antara tanah dengan bahan pencampurnya, yang akan menghasilkan material baru yang memiliki sifat teknis yang lebih baik.

\subsubsection{Stabilisasi Fisik}

Stabilisasi Fisik dilakukan dengan mengenakan enersi dari beban dinamis atau beban statis ke dalam lapisan tanah, sehingga terjadi dekomposisi baru dalam massa tanah yang akan memperbaiki karakteristik lapisan tanah.

\subsubsection{Stabilitas Mekanis}

Stabilisasi Mekanis atau dikenal dengan istilah perkuatan tanah adalah stabilisasi yang dilakukan dengan memasukkan material sisipan ke dalam lapisan tanah sehingga mampu meningkatkan karakteristik teknis dalam massa tanah.

Pada penelitian ini menggunakan prinsip stabilisasi mekanis dengan menggunakan bahan perkuatan, yaitu: (a) Kombinasi kolom-layer pasir; (b) Layer kerikil; (c) Anyaman bambu

\subsection{Daya Dukung Tanah}

Kuat dukung ultimit ( $\mathrm{q}_{\text {ult }}$ ) didefinisikan sebagai beban maksimum per satuan luas dimana tanah masih dapat mendung beban dengan tanpa mengalami keruntuhan [6].

$q_{u l t}=\frac{\text { Pult }}{A}$

dimana: $\mathrm{q}_{\text {ult }}=$ daya dukung ultimit, $\mathrm{P}_{\text {ult }}=$ Beban ultimit, dan $\mathrm{A}=$ Luas area beban atau pondasi 


\subsection{Bearing Capasity Ratio (BCR)}

Bearing Capasity Ratio (BCR) merupakan rasio antara dya dukung ultimit tanah pondasi yang diperkuat dengan daya dukung ultimit tanah pondasi tanpa perkuatan yang dinyatakan dalam persen (\%). Nilai BCR digunakan untuk mengetahui kinerja perkuatan dalam menaikkan daya dukung tanah pondasi.

$\mathrm{BCR}=\mathrm{qult}_{\mathrm{ul}} / \mathrm{q}_{0}$

dimana: $\mathrm{q}_{\text {ult }}=$ Daya dukung ultimit (dengan perkuatan), $\mathrm{q}_{0}$ = Daya dukung ultimit tanah asli

\section{Metode Penelitian}

\subsection{Bahan}

\subsubsection{Tanah Lempung}

Tanah lempung diambil Kasihan, Kabupaten Bantul, Provinsi Daerah Istimewa Yogyakarta. Tanah lempung menjadi obyek utama dalam penelitian ini. Tanah yang digunakan pada pengujian harus dalam kondisi jenuh air.

\subsubsection{Kerikil}

Kerikil yang digunakan dalam penelitian ini memiliki kualitas yang baik dan tidak lapuk. Kerikil yang digunakan bersumber dari Gunung Merapi dan memiliki ukuran butir tertahan di saringan No. 4 (4,75 mm).

\subsubsection{Bambu}

Bambu yang digunakan merupakan jenis Bambu Apus. Kondisi bambu dalam keadaan tidak lapuk dan tidak rapuh. Bambu disusun dalam bentuk anyaman yang terdiri dari lembaran-lembaran dengan lebar $2-5 \mathrm{~cm}$.

\subsubsection{Pasir}

Pasir yang digunakan dalam penelitian ini adalah pasir yang bersumber dari Gunung Merapi dan dalam kondisi tidak lapuk. Pasir yang digunakan dalam pengujian memiliki ukuran butir lolos saringan No. 4 (4,75 mm).

\subsubsection{Air}

Dalam penelitian ini, air digunakan sebagai bahan untuk menjaga tingkat kejenuhan tanah asli. Air disiramkan pada tanah lempung pada saat sebelum pengujian.

\subsection{Set up Pengujian}

Berikut rencana pemasangan peralatan pengujian:

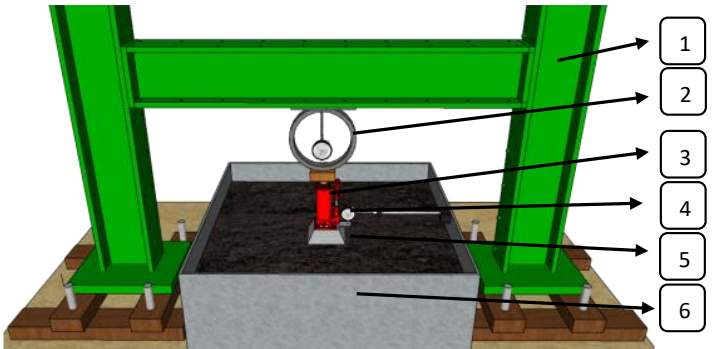

Gambar 2. Set up pengujian

keterangan:

1. Frame baja IWF

2. Proving rings

3. Dongkrak hidraulik

4. Dial gauge

5. Besi pemodelan pondasi

6. Bak uji sampel tanah

\subsection{Tahapan Penelitian}

Tahapan penelitian secara urut disajikan dalam diagram alir berikut ini:

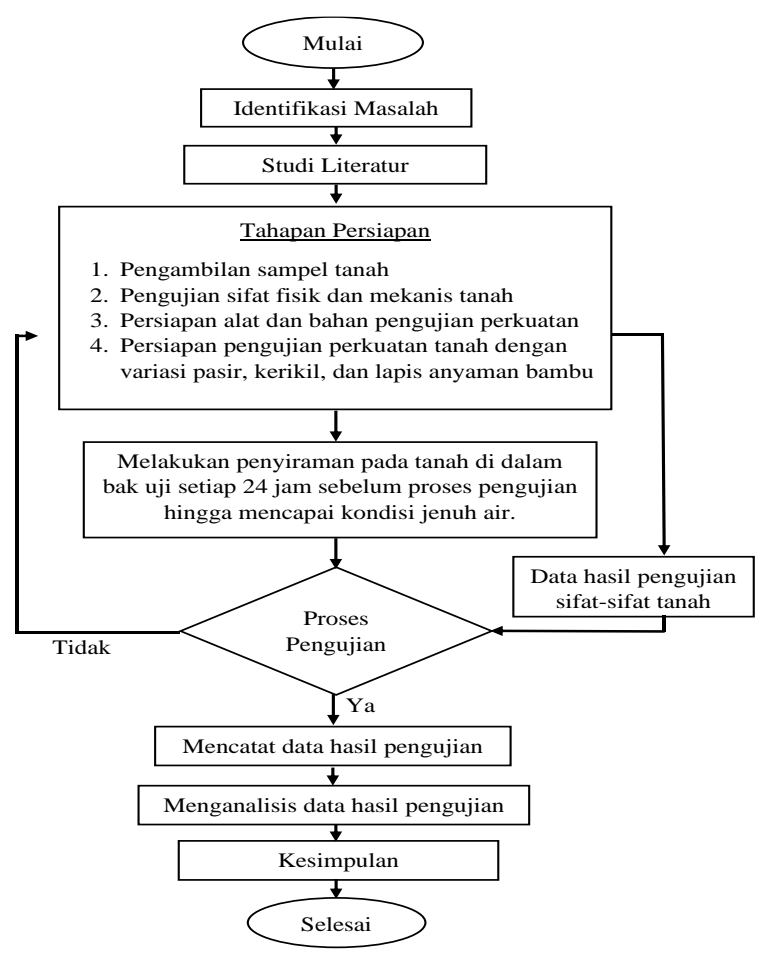

Gambar 3. Diagram alir penelitian

Permasalahan utama yang diangkat melalui penelitian ini adalah tanah lempung yang mempunyai karakteristik daya dukung yang rendah dan kompresibilitas yang tinggi sehingga tidak layak sebagai tumpuan sebuah bangunan. 


\subsubsection{Studi Literatur}

Studi literatur merupakan tahapan mencari referensi penelitian yang relevan dengan permasalahan yang akan diangkat. Sumber dari teori-teori yang digunakan dalam penelitian ini utamanya berasal dari laporan penelitian, tugas akhir dan beberapa jurnal pada penelitian sebelumnya.

\subsubsection{Tahap Persiapan}

Tahap persiapan meliputi pengambilan sampel tanah, pengujian sifat fisik dan mekanis tanah, persiapan pengujian tanah asli, dan persiapan pengujian perkuatan tanah.

Pengambilan sampel tanah dilakukan di Kecamatan Kasihan, Kabupaten Bantul, Provinsi Daerah Istimewa Yogyakarta. Pengambilan sampel menggunakan hand auger dan tabung sampel. Pengujian sifat fisik meliputi pengujian kadar air, berat jenis, batas atterberg, dan analisi ukuran butir. Pengujian sifat mekanis tanah meliputi pengujian pemadatan, pengembangan, CBR, geser langsung, triaksial, dan tekan bebas.

Pesiapan alat meliputi pemasangan rangkaina alat pengujian (set up) yang terdiri dari bak uji, besi model pondasi, dial gauge, dongkrak hidrolis, proving ring, dan frame baja IWF. Persiapan bahan pengujian yaitu menempatkan sampel tanah lempung ke dalam bak uji. Proses pengisian tanah ke dalam bak uji dilakukan secara bertahap dengan cara dipadatkan menggunakan palu kayu. Tanah diisi secara bertahap dengan ketebalan lapisan $5 \mathrm{~cm}$ dan diisi hingga mencapai tebal $30 \mathrm{~cm}$.

Pengujian perkuatan tanah dibagi menjadi 4 macam yaitu pengujian tanah asli tanpa perkuatan, pengujian perkuatan dengan layer kerikil, pengujian perkuatan dengan anyaman bambu, dan pengujian perkuatan dengan gabungan kolom pasir dan layer pasir. Pembuatan pola gabungan kolom pasir dan layer pasir terdiri dari 3 lapis pasir dengan posisi horizontal dengan tebal $1 \mathrm{~cm}$ dan jarak antar lapisan $5 \mathrm{~cm}$. Kolom pasir dengan diamter $1 \mathrm{~cm}$ dan dengan kedalaman lubang $20 \mathrm{~cm}$. Pembuatan pola layer kerikil yaitu terdiri dari 3 lapis kerikil dengan ketebalan lapisan $2 \mathrm{~cm}$ dan jarak antar lapisan $5 \mathrm{~cm}$. Pembuatan pola anyaman bambu yaitu 1 lapis dengan panjang dan lebar anyaman yaitu 20x20 cm. Penempatan anyaman pada kedalaman $2 \mathrm{~cm}$ dari permukaan sampel tanah.

Sebelum dilakukannya pengujian, sampel tanah disiram terlebih dahulu dengan air secukupnya. Penyiraman air dilakukan setiap 24 jam sebelum pengujian dilaksanakan. Penambahan air dilakukan agar tanah tetap dalam kondisi jenuh air. Pengujian dilakukan dengan memberikan beban secara bertahap dengan menggerakkan tuas dongkak hidrolis dan menyelaraskan dengan putaran jarum dial gauge dengan pembacaan 1 putaran jarum dial gauge selama 1 menit. Proses pengujian dihentikan apabila tanah sudah mengalami keruntuhan. Pencatatan hasil pengujian berupa beban yang terukur pada proving ring dan jumlah penurunan tanah.

Hasil dari pengujian, diolah dan dianalisis mengunakan aplikasi Microsoft Excel. Adapun hasil yang diperoleh, adalah sebagai berikut: (a) membandingkan pengaruh setiap bahan perkuatan yang telah diuji; (b) menghitung perubahan kadar air dan penurunan tanah; (c) menghitung beban ultimit (Pult) setiap bahan perkuatan; (d) menghitung kuat dukung ultimit (qult) setiap bahan perkuatan; (e) membandingkan daya dukung pada setiap pengujian variasi bahan perkuatan dengan pengujian tanpa bahan perkuatan; (f) membandingkan nilai Bearing Capacity Ratio (BCR) dari setiap bahan perkuatan.

\section{Hasil dan Pembahasan}

\subsection{Hasil Pengujian Sifat-sifat Tanah}

Tabel 1. Hasil pengujian sifat fisik dan mekanis tanah lempung

\begin{tabular}{|c|c|c|c|}
\hline No. & \multicolumn{2}{|c|}{ Jenis Pengujian } & Hasil \\
\hline \multirow[t]{2}{*}{1.} & \multirow[t]{2}{*}{ Kadar Air } & $\omega$ & $32,10 \%$ \\
\hline & & LL & $75,57 \%$ \\
\hline \multirow[t]{2}{*}{2.} & \multirow[t]{2}{*}{ Batas Atterberg } & PL & $29,76 \%$ \\
\hline & & PI & $44,95 \%$ \\
\hline 3. & Berat Jenis & Gs & 2,689 \\
\hline \multirow{2}{*}{4.} & \multirow{2}{*}{ Pemadatan } & OMC & $39,20 \%$ \\
\hline & & $\Gamma \mathrm{d}$ & $1,232 \mathrm{~kg} / \mathrm{cm}^{2}$ \\
\hline \multirow{2}{*}{5.} & \multirow{2}{*}{ CBR } & $0,1 ”$ & $8,116 \%$ \\
\hline & & $0,2 ”$ & $6,261 \%$ \\
\hline \multirow[t]{2}{*}{6.} & \multirow[t]{2}{*}{ Kembang- Susut } & S & $0,73 \%$ \\
\hline & & $\mathrm{C}$ & $0,011 \mathrm{~kg} / \mathrm{cm}^{2}$ \\
\hline \multirow[t]{2}{*}{7.} & \multirow[t]{2}{*}{ Kuat Geser } & $\Phi$ & $28,1^{\circ}$ \\
\hline & & $\mathrm{Qu}$ & $3,197 \mathrm{~kg} / \mathrm{cm}^{2}$ \\
\hline \multirow{2}{*}{8.} & \multirow{2}{*}{ Klasifikasi Tanah } & USCS & $\mathrm{CH}$ \\
\hline & & AASHTO & A-7-6 (40) \\
\hline
\end{tabular}

Secara umum dapat dilihat bahwa apabila beban diatas tanah pondasi yang dilakukan penambahan beban secara bertahap, penurunan pun akan semakin bertambah, hingga beban yang terukur pada proving ring tidak mengalami penambahan. Jadi pada kondisi tersebut menunjukkan 
bahwa telah mencapai pada kuat dukung ultimit. Hal ini juga dapat diilustrasikan pada saat mulai pembebanan maka penurunan yang relatif kecil dan bertambah secara perlahan seiring bertambahnya beban. Kemudian akibat pembebanan beban terjadi penurunan yang semakin besar hingga tanah pondasi mengalami penurunan maksimum (runtuh). Adanya bahan perkuatan meningkatkan.

\subsection{Beban Ultimit}

Beban ultimit $\left(\mathrm{P}_{\mathrm{ult}}\right)$ diperoleh dari pertemuan antara perpotongan dari garis singgung awal dan garis lurus pada akhir kurva. Besarnya beban ultimit pada saat pondasi mengalami keruntuhan $\left(\mathrm{P}_{\mathrm{ult}}\right)$ untuk pengujian tanah asli dan variasi bahan perkuatan adalah sebagai berikut:

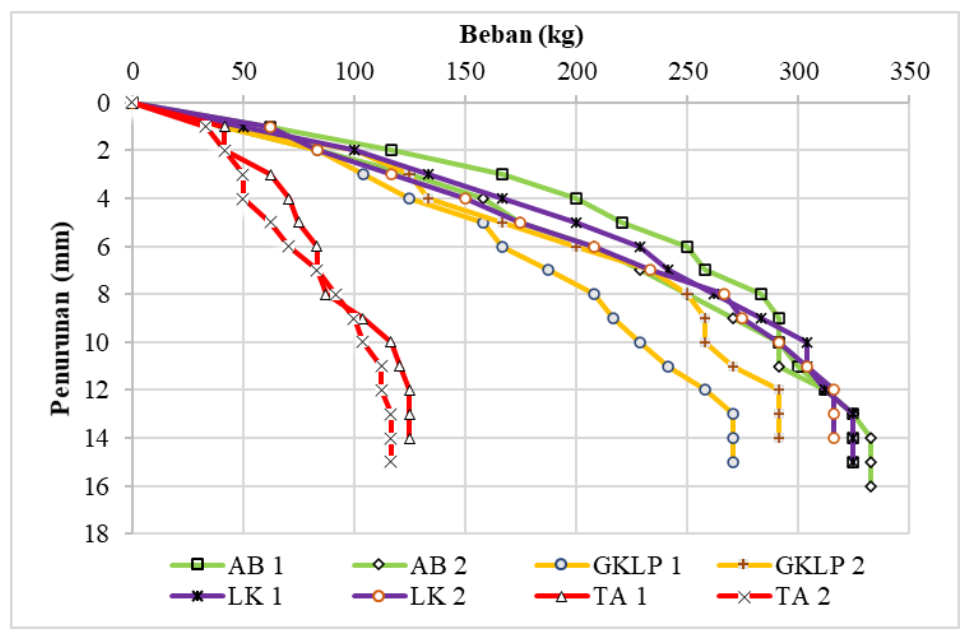

Gambar 4. Grafik hubungan beban dan penurunan

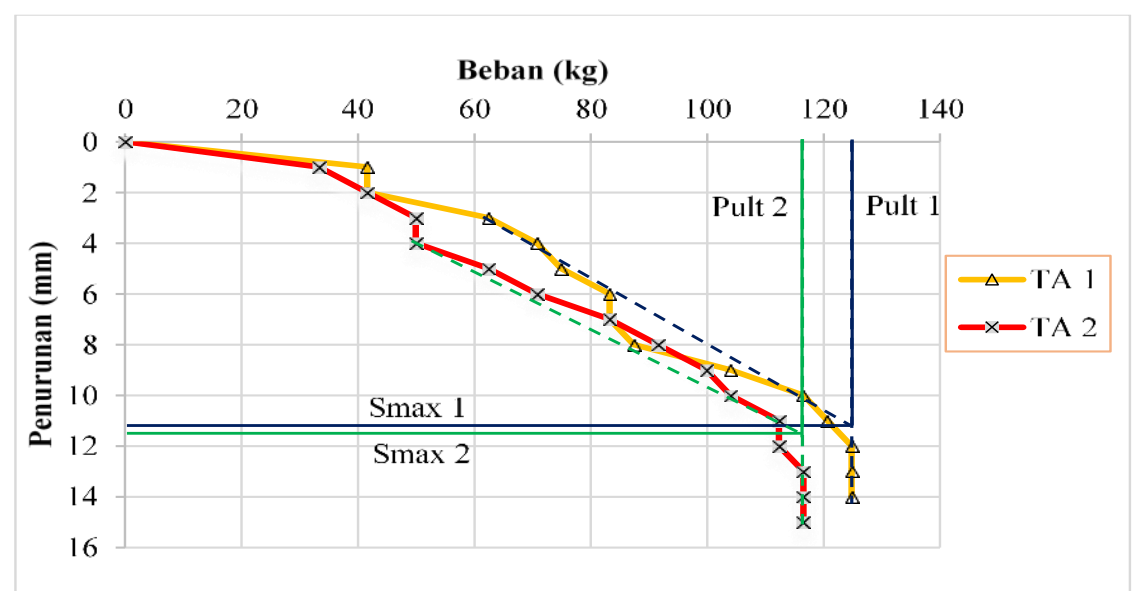

Gambar 5. Grafik pult perkuatan tanah asli

Beban ultimit yang diperoleh dari pengujian tanah lempung tanpa perkuatan adalah $121,5 \mathrm{~kg}$.

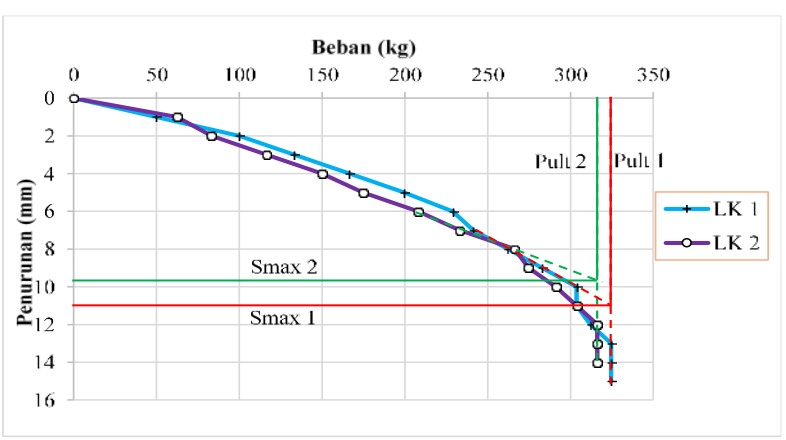

Gambar 6. Grafik pult perkuatan layer kerikil
Beban ultimit yang diperoleh dari pengujian tanah lempung dengan perkuatan layer kerikil adalah $317,5 \mathrm{~kg}$.

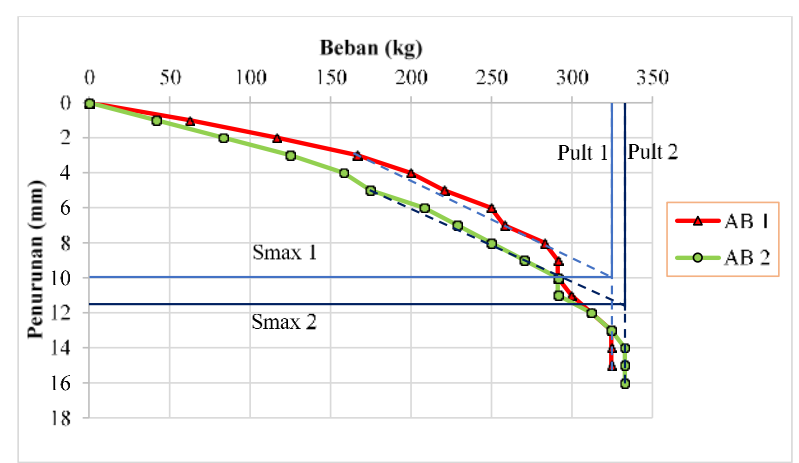

Gambar 7. Grafik pult perkuatan anyaman bambu 
Beban ultimit yang diperoleh dari pengujian tanah lempung dengan perkuatan anyaman bambu adalah 330 $\mathrm{kg}$.

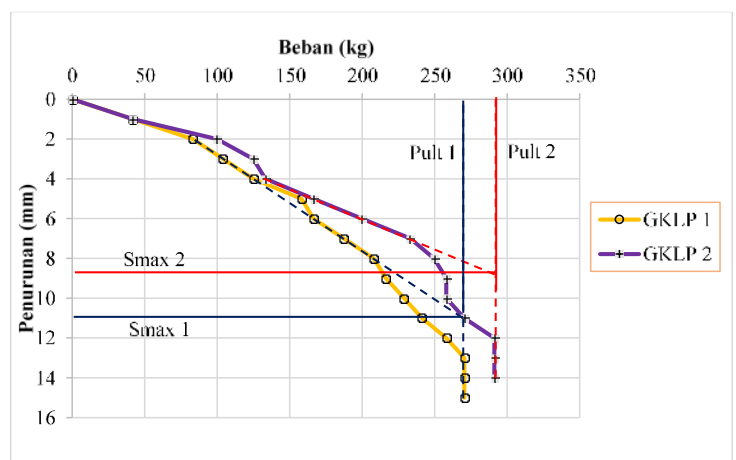

Gambar 8. Grafik Pult Perkuatan Gabungan Pasir
Beban ultimit yang diperoleh dari pengujian tanah lempung dengan perkuatan gabungan kolom pasir dan layer pasir adalah $280 \mathrm{~kg}$.

\subsection{Daya Dukung Ultimit}

Parameter daya dukung ultimit diperoleh dari hasil beban ultimit per satuan luas. Hasil kuat dukung ultimit dapat dilihat pada Gambar 9.

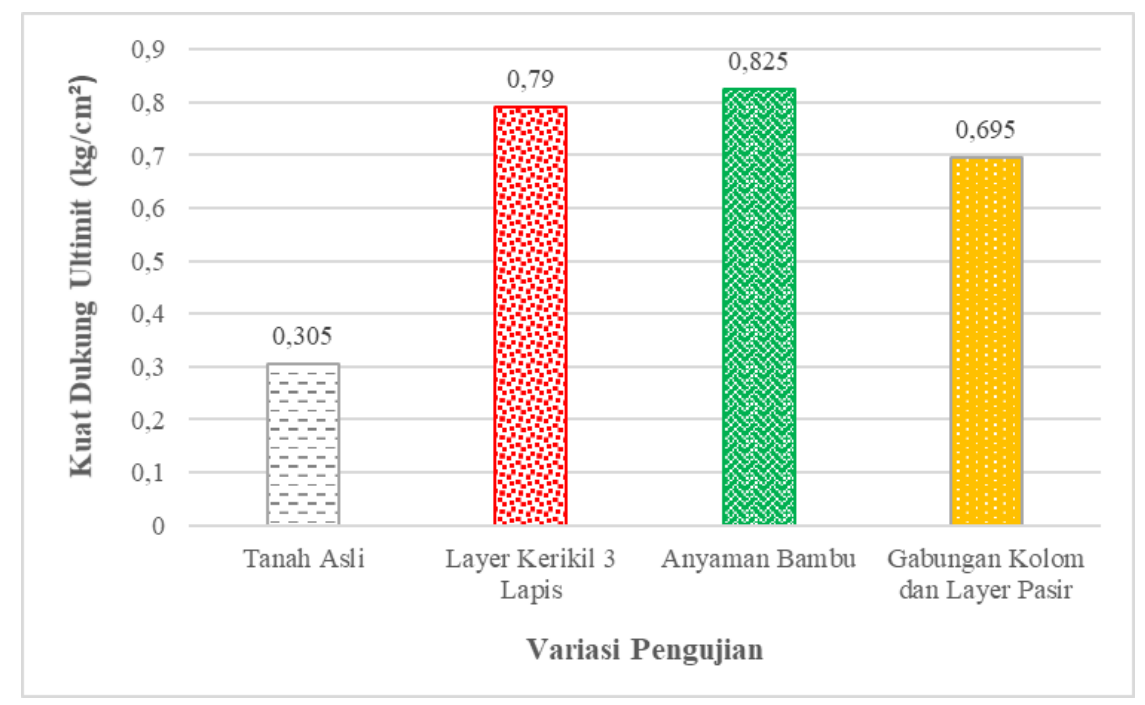

Gambar 9. Kuat dukung ultimit pada variasi bahan perkuatan

Dari Gambar 9 dapat dilihat bahwa adanya peningkatan daya dukung ultimit pada tanah lempung lunak karena adanya bahan perkuatan yaitu layer kerikil, anyaman bambu dan gabungan kolom pasir dan layer pasir dengan nilai daya dukung ultimit berturut-turut sebesar 0,79 $\mathrm{kg} / \mathrm{cm}^{2} ; 0,825 \mathrm{~kg} / \mathrm{cm}^{2} ; 0,695 \mathrm{~kg} / \mathrm{cm}^{2}$. Pada pengujian tanah asli tanpa perkuatan hanya memiliki daya dukung ultimit sebesar $0,305 \mathrm{~kg} / \mathrm{cm}^{2}$. Hasil ini menunjukkan penambahan bahan perkuatan baik itu layer kerikil, anyaman bambu, dan gabungan kolom pasir dan layer pasir mampu untuk memperkuat tanah lempung. Selain itu, dari gambar 45 dapat diketahui bahwa bahan perkuatan anyaman bambu memiliki daya dukung ultimit paling tinggi yaitu sebesar $0,825 \mathrm{~kg} / \mathrm{cm}^{2}$, dibandingkan dengan bahan perkuatan layer kerikil dan gabungan kolom pasir dan layer pasir.

\subsection{Nilai BCR}

Bearing Capacity Ratio atau BCR merupakan nilai yang digunakan untuk menyatakan peningkatan daya dukung tanah pondasi dengan membandingkan antara daya dukung ultimit tanah yang diperkuat $\left(\mathrm{q}_{\mathrm{ult}}\right)$ dengan daya dukung tanah asli $\left(\mathrm{q}_{0}\right)$ dan dinyatakan dalam persen $(\%)$.

Dari hasil pengujian pembebanan dan analisis data yang telah dilakukan pada bahan perkuatan yang digunakan yaitu layer kerikil, anyaman bambu, dan gabungan kolom pasir dan layer pasir, dapat dikatakan penggunaan bahanbahan perkuatan tersebut meningkatkan nilai BCR, terbukti dari nilai BCR dari masing-masing bahan perkuatan yang memiliki nilai BCR yang lebih tinggi dari nilai BCR tanah asli. Besarnya rasio daya dukung dan presentase peningkatannya dapat dilihat dalam Tabel 2. 
Tabel 2. Rekapitulasi daya dukung, BCR, dan peningkatan BCR

\begin{tabular}{lccc}
\multicolumn{4}{c}{ peningkatan BCR } \\
\multicolumn{1}{c}{ Variasi } & $\begin{array}{c}\text { qult rata-rata } \\
\left(\mathrm{kg} / \mathrm{cm}^{2}\right)\end{array}$ & BCR & \% Peningkatan \\
\hline Tanah Asli & 0.305 & 1 & - \\
Layer Kerikil & 0.790 & 2.5902 & 159.02 \\
Anyaman Bambu & 0.825 & 2.7049 & 170.49 \\
Gabungan Pasir & 0.695 & 2.2787 & 127.87 \\
\hline
\end{tabular}

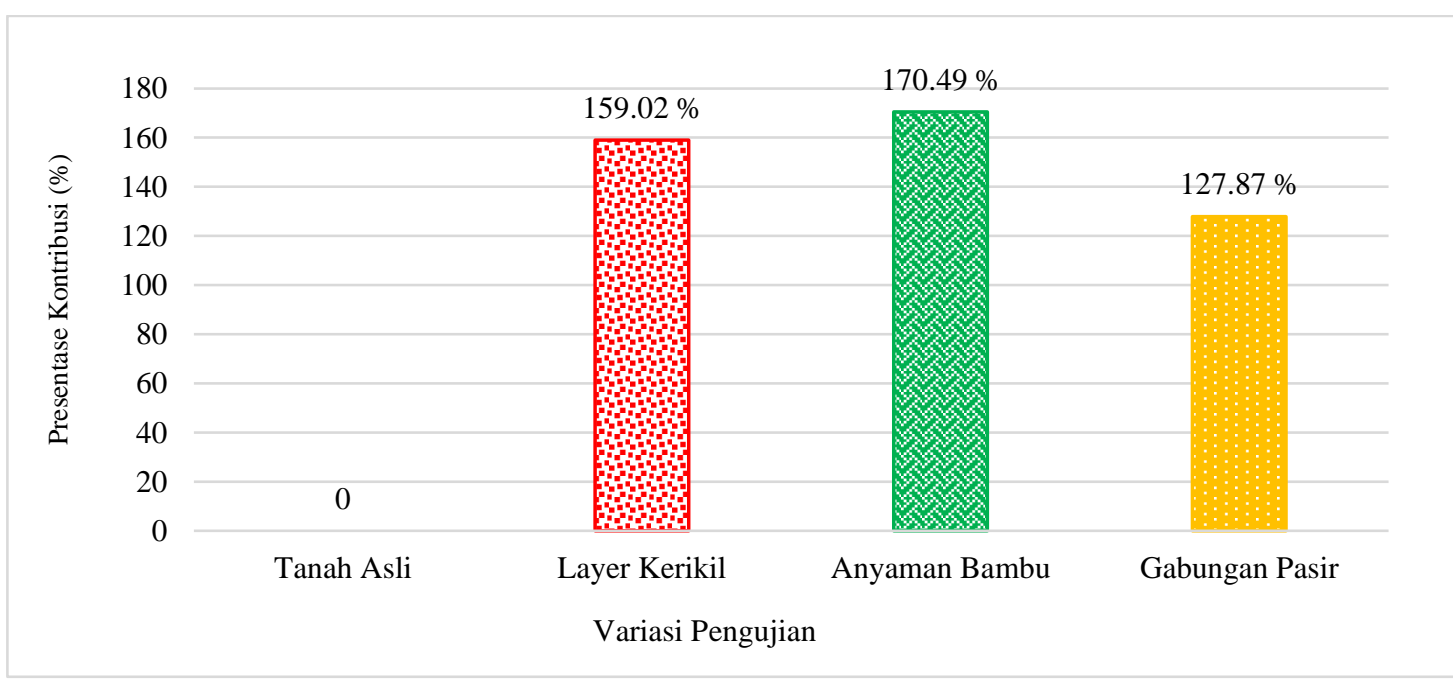

Gambar 10. Grafik hubungan presentase kontribusi terhadap daya dukung ultimit

Dari Gambar 10 dapat diketahui bahwa perkuatan tanah dengan bahan anyaman bambu mengalami peningkatan yang tertinggi. Anyaman bambu memberikan peningkatan kontribusi daya dukung ultimit paling besar yaitu 170,49 $\%$, hal itu dikarenakan anyaman bambu memiliki kuat tarik yang cukup untuk menambah daya dukung. Pada perkuatan anyaman bambu, beban yang diberikan pada pondasi akan menimbulkan perubahan atau deformasi pada anyaman bambu. Akibat dari deformasi akan menimbulkan gaya tarik pada anyaman bambu. Gaya tarik tersebut akan menghambat laju penurunan tanah dan mengurangi beban yang bekerja saat pengujian berlangsung, sehingga daya dukung tanah akan meningkat. Pemasangan anyaman bambu secara horizontal juga menjadi faktor yang mempengaruhi perlambatan beban.

\subsection{Kadar Air}

Pengambilan sampel kadar air pada kedalaman $10 \mathrm{~cm}$ dan $20 \mathrm{~cm}$ bertujuan untuk mengetahui nilai kadar air yang terjadi akibat pengaruh dari masing-masing bahan perkuatan. Pengambilan kadar air dilakukan setelah selesainya pengujian pada setiap bahan perkuatan

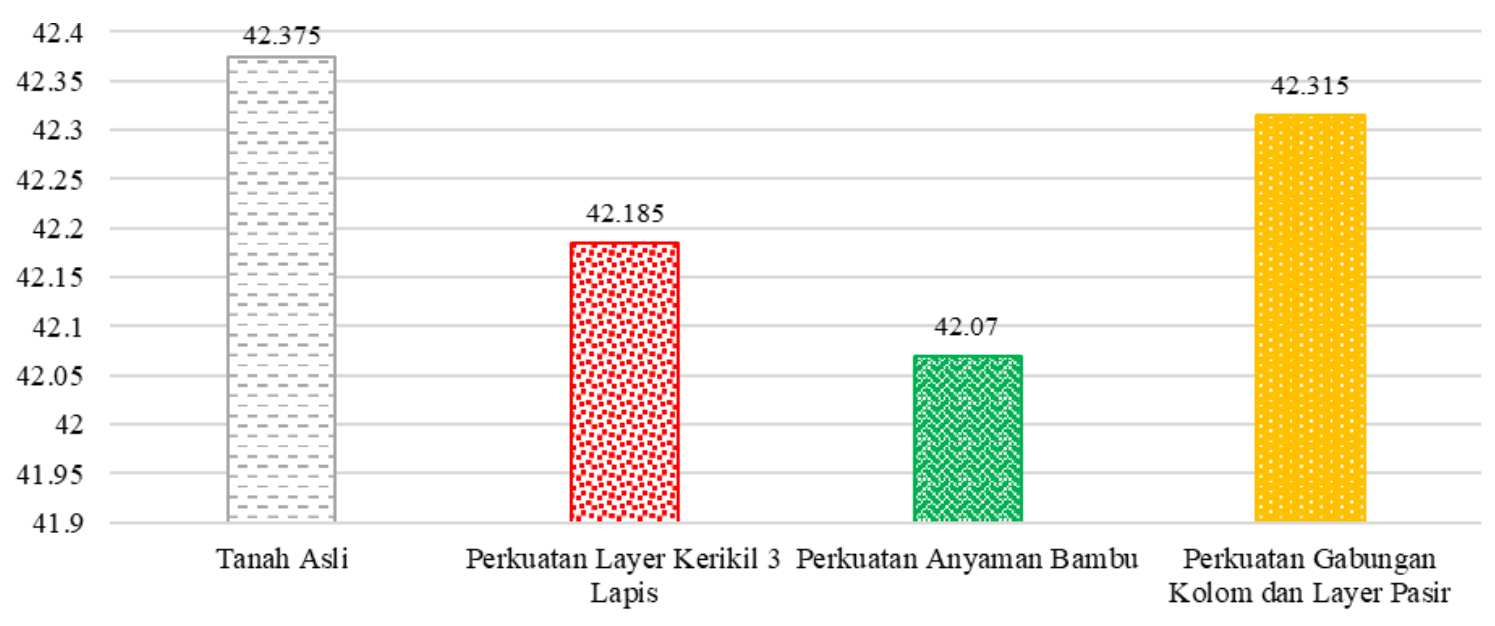

Gambar 11. Persentase Kadar Air Setelah Pembebanan 
Gambar 11 melaporkan tentang persentase kadar air pada setiap variasi pengujian maka dapat diketahui bahwa penggunaan anyaman bambu lebih efektif dalam mengurangi kadar air pada tanah lempung lunak dengan nilai $0,305 \%$, sedangkan penggunaan gabungan kolom dan layer pasir sebesar 0,006 \% dan bahan layer kerikil sebesar $0,19 \%$.

\section{Simpulan}

Sesuai dengan hasil dan pembahasan penelitian diperoleh beberapa kesimpulan sebagai berikut: (a) berdasarkan klasifikasi tanah sistem USCS, tanah yang menjadi bahan penelitian termasuk jenis tanah Lempung anorganik dengan plastisitas tinggi atau (clay high plastisity) dengan kode $\mathrm{CH}$. Sedangkan berdasarkan klasifikasi tanah sistem AASHTO, tanah termasuk dalam kelompok A-7-6 (40) yaitu tanah berlempung dengan kondisi sedang sampai buruk; (b) Penggunaan bahan perkuatan layer kerikil meningkatkan daya dukung ultimit sebesar 2,5 kali atau persen peningkatannya $159,02 \%$, sedangkan anyaman bambu memberikan peningkatan daya dukung sebesar 2,7 kali atau persen peningkatannya $170,49 \%$, dan gabungan kolom pasir dan layer pasir sebesar 2,2 kali atau 127, 87 $\%$; (c) Penggunaan bahan perkuatan anyaman bambu memberikan peningkatan daya dukung paling tinggi pada tanah lempung lunak diantara bahan perkuatan layer kerikil dan perkuatan gabungan kolom pasir dan layer pasir. Hal ini menunjukkan bahwa penggunaan anyaman bambu lebih efektif sebagai bahan perkuatan tanah lempung.

\section{Daftar Rujukan}

[1] Wibowo, D. E. (2020, September). Strengthening and Supporting Efforts to Reduce Swelling of Soil by Using Beach Sands Through CBR Test. In Journal of Physics: Conference Series (Vol. 1625, No. 1, p. 012008). IOP Publishing.

[2] Usman, Angelina. 2014. Studi Daya Dukung Pondasi Dangkal pada Tanah Gambut Menggunakan Kombinasi Perkuatan Anyaman Bambu dan Grid Bambu dengan Variasi Lebar dan Jumlah Lapisan Perkuatan. Palembang: Jurnal Teknik Sipil.

[3] Wibowo, D. E., \& Kurniawan, R. (2020). Pengaruh Penggunaan Kolom Pasir, Layer Pasir, Dan Terucuk
Bambu Pada Tanah Lempung Jenuh Air Terhadap Penurunan Tanah Lempung Menggunakan Uji Laboratorium. Informasi dan Ekspose hasil Riset Teknik SIpil dan Arsitektur, 16(1), 64-73.

[4] Risdanta, R.H., 2018. Perencanaan Perbaikan Tanah Lunak Menggunakan Preloading dengan Kombinasi Prefebricated Vertical Drain (PVD) dan Prefebricated Horizontal Drain (PHD) pada Pembangunan Kawasan Kota Summarecon Bandung Area Amanda dan Btari. Skripsi. Malang: Universitas Brawijaya.

[5] Nusantara, M.A. 2014. Analisa Daya Dukung Pondasi Dangkal pada Tanah Lempung Menggunakan Perkuatan Anyaman Bambu dan Grid Bambu dengan Bantuan Program Plaxis. Palembang: Jurnal Teknik Sipil Universitas Sriwijaya.

[6] Hardiyatmo, Hary Christiady, 2002. Mekanika Tanah 1 Edisi Ketiga. Yogyakarta: Universitas Gajah Mada Press.

[7] Terzaghi, K. dan R.B. Peck, 1987. Mekanika Tanah dalam Praktek Rekayasa Jilid I. Jakarta: Erlangga.

[8] Suwartanti, 2005. Perilaku Mekanik Tarik Bambu dan Potensi Aplikasinya sebagai Perkuatan Tanah pada Timbunan. Yogyakarta: Jurnal Teknik Sipil.

[9] Ananda S, Ichikawa Y, Munelata, Nagase Y dan Shimizu H., 1996. Fiber Texture and Mechanical Graded Structure of Bamboo. Dep. of Mechanical Engineering, Gumme University Japan

[10] Morisco, 1999. Rekayasa Bambu. Pusat Antar Universitas untuk Teknik Sipil UGM. Yogyakarta.

[11] ASTM C33 Standard Specification for Concrete Aggregates.

[12] Muhiddin, A.B. 2016. Studi Pengaruh Perkuatan Tanah Model Trapesium Terhadap Daya Dukung Tanah Lempung. Makasar: Jurnal Teknik Sipil.

[13] Wesley, L.D.,2012. Mekanika Tanah untuk Tanah Endapan \& Residu. Yogyakarta: Andi.

[14] Wibowo, D. E. (2020, September). Strengthening and Supporting Efforts to Reduce Swelling of Soil by Using Beach Sands Through CBR Test. In Journal of Physics: Conference Series (Vol. 1625, No. 1, p. 012008). IOP Publishing.

[15] Nurindah, S., 2017. Perilaku Pondasi Telapak yang Diperkuat Kolom Pasir Terhadap Pembebanan. Tugas Akhir. Surakarta: Universitas Muhammadiyah Surakarta. 